\title{
Contents volume 88
}

Contents volume 88 , No. 1

Editorial

Geoperspective | Climate-proofing the flood protection of the Netherlands

P. Vellinga, N. Marinova \& J.M. van Loon-Steensma

From river valley to estuary: the evolution of the Rhine mouth in the early to middle Holocene (western Netherlands,

Rhine-Meuse delta)

M.P. Hijma, K.M. Cohen, G. Hoffmann, A.J.F. Van der Spek \& E. Stouthamer

Provenance of basalt blocks from Roman sites in Vleuten-De Meern (the Netherlands) traced to the Tertiary

Siebengebirge (Germany): a geoarchaeological quest using petrological and geochemical methods

K. Linthout, H. Paulick \& J.R. Wijbrans

A comparative analyses of microstructures from Late Jurassic diamictic units, near Helmsdale, northeast Scotland and a Pleistocene diamicton from near Milton, southern Ontario, Canada - a differential diagnostic method of sediment 'typing' using micromorphology

J. Menzies \& C. Whiteman

\section{Contents volume 88 , No. 2}

Assessing $\mathrm{CH}_{4}$ and $\mathrm{CO}_{2}$ emissions from wetlands in the Drenthe Province, the Netherlands: a modelling approach

A.M.R. Petrescu, J. van Huissteden, F. de Vries, E.P.H. Bregman \& A. Scheper

Holocene, Weichselian Late-glacial and earlier Pleistocene deposits of the upper Cam valley at the Hinxton Genome Campus, Cambridgeshire, UK

S. Boreham \& C.J. Rolfe

Geo(Im)pulse | A late Miocene astropectinid (Echinodermata, Asteroidea) and associated ichnofossils from Liessel, province of Noord-Brabant, the Netherlands

J.W.M. Jagt, R.H.B. Fraaije \& B.W.M. van Bakel 


\section{Contents volume 88 , No. 3}

Unravelling the enigmas of the 'silver sands' in the Dutch/German/Belgian border area

A.J. van Loon

Silica sand resources in the Netherlands

M.J. van der Meulen, W.E. Westerhoff, A. Menkovic, S.H.L.L. Gruijters, C.W. Dubelaar \& D. Maljers

A new species of the durophagous mosasaur Carinodens (Squamata, Mosasauridae) and additional material

of Carinodens belgicus from the Maastrichtian phosphates of Morocco

A.S. Schulp, N. Bardet \& B. Bouya

Geo(Im)pulse | Bite marks on early Holocene Tursiops truncatus fossils from the North Sea indicate scavenging by rays (Chondrichthyes, Rajidae)

H.H. van Netten \& J.W.F. Reumer

Correspondence | A comment on the paper 'Solar activity and its influence on climate'

C. Amory-Mazaudier \& J-P. Legrand

Correspondence | Reply by C. de Jager on the comment by C. Amory-Mazaudier and J-P. Legrand

\section{Contents volume 88 , No. 4}

Late Moscovian terrestrial biotas and palaeoenvironments of Variscan Euramerica

Editors: C.J. Cleal, S. Opluštil, B.A. Thomas \& Y. Tenchov 